\title{
Living conditions and public health status in three urban slums of Lagos, Nigeria
}

\author{
Akinwale $O P^{l}$, Adeneye $A K^{2}$, Musa $A Z^{3}$, Oyedeji $K S^{4}$, Sulyman $M A^{5}$, Oyefara $J O^{6}$, Adejoh $P E^{7}$, \\ Adeneye $A A^{8}$
}

${ }^{1}$ Director of Research (Neglected Tropical Diseases), Head, Molecular Parasitology Research Laboratory, Public Health Division; ${ }^{2,5}$ Research Fellow, Public Health Division; ${ }^{3}$ Research Fellow, Clinical Sciences Division; ${ }^{4}$ Research Fellow,

Molecular Biology and Biotechnology Division; Nigerian Institute of Medical Research, Yaba, Lagos state, Nigeria.

${ }^{6,7}$ Lecturer, Department of Sociology, Faculty of Social Sciences, University of Lagos, Akoka, Yaba, Lagos state, Nigeria.

${ }^{8}$ Lecturer, Department of Pharmacology, Faculty of Basic Medical Sciences, Lagos State University College of Medicine, Ikeja, Lagos State, Nigeria.

\begin{abstract}
Lagos metropolis, southwestern Nigeria, is faced with environmental problems ranging from slums and informal settlements, to crime and delinquency. The aim of the study was to explore the demographic characteristics, migration history and living conditions of 2,434 residents of Ajegunle, Ijora Oloye and Makoko in Lagos metropolis. A cross-sectional survey was conducted between June 2010 and October 2012 using a semi-structured questionnaire. Units of analysis used were households. Many of the respondents are low-income earners working in the informal service sectors, and living in unhygienic conditions. The communities are densely populated, with more than five people living in a room. Residents make use of poor and overstressed facilities and inadequate water and electricity supplies. They also lack appropriate garbage disposal facilities and good drainage. Personal hygiene habits are very poor; open defecation in ditches and the lagoon is widely practiced. Respondents are faced with perennial flooding due to blocked drainage systems resulting in a number of diseases, such as malaria, diarrhea, cold and cough. Migration has led to uncontrolled and unplanned developments of slums in metropolitan Lagos. This in turn has led to poverty, unemployment, illiteracy, polluted environment, uncontrolled population growth and health problems in the slums as are observed in this study. There is an urgent need for comprehensive interventions from the government and other organizations to strengthen existing programs to improve the health and quality of life of this vulnerable population.
\end{abstract}

Keywords: Living conditions, Diseases, Urban slums, Quality of life, Nigeria.

\section{Introduction}

The United Nations Human Settlements (UNHS) gave a comprehensive global description of urban slum communities and attempted to identify different approaches to address this problem in order to achieve the United Nations Millennium Development Goals (MDGs). ${ }^{1}$ The UNHS defines a slum variously as a wide range of lowincome settlements and/or poor human living conditions. ${ }^{1}$ This includes the vast informal settlements that are quickly becoming the most visual expression of urban poverty. The quality of dwellings in such settlements varies from the simple shack to permanent structures, while access to water, electricity, sanitation and other basic services and infrastructure tends to be limited. ${ }^{1,2}$ Slum dwellers occupy irregular settlements, squatter housing, unauthorized land developments, rooms and flats in dilapidated and uncompleted buildings ${ }^{3}$, and Nigeria has a fair share of these irregular settlements where there growth is $4.23 \%$ with urban population in $2007 .{ }^{4}$ However, due to the informal nature of slum settlements, and cultural, social, and behavioral factors unique to slum populations, little is known about the challenges they face in terms of health and quality of life. The Nigerian Demographic and Health Survey (NDHS) is conducted periodically, and although urban areas are surveyed, slums are not specifically investigated. Consequently lack of health-related

\section{Practice Points}

- Majority of slum dwellers in Lagos Nigeria migrate to cities for economic reasons, and suffer unacceptable levels of hygiene and health, while they are deprived of essential basic social facilities.

- The communities are densely populated, with more than five people living in a room.

- Respondents make use of poor and overstressed facilities, inadequate water and electricity supplies, while they also lack proper garbage disposal facilities and good drainages.

- Poor personal hygiene habits and open defecation in ditches are widely practiced while poor environment causes a number of diseases (e.g. malaria, diarrhea, cold and cough).

- There is an urgent need for comprehensive interventions to improve the health and quality of life of this vulnerable population.

Correspondence: Dr. Akinwale O. P., Director of Research (Neglected Tropical Diseases), Head, Molecular Parasitology Research Laboratory, Public Health Division, Nigerian Institute of Medical Research, P.M.B. 2013 Yaba, Lagos. Nigeria. E-mail: pheabian@yahoo.co.uk.

South East Asia Journal of Public Health 2013;3(1):36-41. (C) 2013 Akinwale et al., publisher and licensee Public Health Foundation Bangladesh. This is an Open Access article which permits unrestricted non-commercial use, provided the original work is properly cited. 
data from slums could lead to inappropriate and unrealistic allocation of healthcare resources by the public and private health providers.

Lagos state, southwestern Nigeria, has a population of about 17 million out of a national estimate of 150 million. Of this population, metropolitan Lagos, an area covering $37 \%$ of the land area of Lagos State, southwestern Nigeria, is home to over $85 \%$ of the state population. ${ }^{5}$ The metropolis is an old Yoruba town, beginning in the $15^{\text {th }}$ century and grew as a trade centre as well as seaport. ${ }^{6}$ Lagos metropolis represents the epitome of urban decay replete with environmental problems ranging from slums and squatter settlements, to crime and delinquency. The high population growth rate of Lagos has been largely attributed to rural-urban migration which accounts for up to $75 \%$ of the population increase. $^{7}$ This growth rate, reaching up to $6 \%$ over the last decade, has translated into unusual pressure, leading to an unprecedented demand for land. It is therefore a common phenomenon to see most undeveloped land being taken over by the rural immigrants to satisfy their urban land needs. ${ }^{8}$ Such invasions usually lead to uncontrolled and unorganized developments of slum communities which lack basic infrastructural facilities and are characterized by very poor environmental conditions. In this study, we aimed to study the demographic characteristics, migration history, and living and health conditions of the residents of three slums in Lagos metropolis.

\section{Materials and methods}

\section{Study population}

The study population consists of individuals who are 15 years and above living permanently in Ajegunle in Ajeromi Ifelodun Local Government Area (LGA), Ijora Oloye in Apapa LGA and Makoko in Mainland LGA. The current populations (Ajegunle - 429,381; Ijora Oloye - 18,278; Makoko - 141,277) were calculated based on the projected growth rate of $7.5 \%$ using the 2006 national census figures ${ }^{8}$ as baseline. Sample size of single proportion method using EPI Info version 6 was used to calculate the sample size. ${ }^{9}$

\section{Research design and sampling techniques}

A multi-stage sampling method was used to sample household members across different socioeconomic background in the three study locations. The first stage involved stratification of each community into two groups on the basis of geographical closeness. The second stage was the clustering of each of the two groups into different enumeration areas (EAs) on the basis of existing delineation by the National Population Commission of Lagos State in the 2006 population census exercise. ${ }^{8}$ The third stage involved random selection of four EAs from each of the three selected communities. The fourth stage involved systematic random sampling by numbering houses in each of the selected EAs, and randomly selecting houses from the numbered ones within each of the strata. The final stage was the random sampling of households from each of the sampled houses.
A simple random technique was also used to select eligible households within a sampled building, which was proportional to the population size of the community, while a household sample was drawn randomly to allow for degree of representativeness. The units of analysis for the survey were households in the selected three communities and the survey tool was a pre-tested semistructured questionnaire. The questionnaire was used to interview the respondents of the sample households to seek information on both quantifiable and nonquantifiable factors, which included migration, household annual income, and living and health conditions.

\section{Ethical consideration and consent documentation}

Prior to the commencement of the project, ethical clearance was obtained from the Institutional Review Board of the Nigerian Institute of Medical Research. Informed consent of the leaders and stakeholders in the three communities was received. Permission to carry out the project in the selected communities was obtained from the three LGA authorities overseeing the three communities.

\section{Result}

Respondents were interviewed directly using a personal interview method in order to avoid incomplete information. A sample of 2,434 respondents was recruited between June and October 2010 from Ijora Oloye (805), Ajegunle (814) and Makoko (815) communities. Table 1 shows the demographic and socio-economic characteristics of the respondents. The respondents consisted largely of migrants from all parts of the country with the dominant groups being the Ijaw, Ilaje, Hausa, Ibo, Urhobo and Yoruba ethnicity. Various languages were used to interview the respondents as shown in Table 2.

Many respondents from Ijora Oloye (443 or 55.0\%) and Makoko (416 or $51.0 \%$ ) were born in the slum areas, compared to Ajegunle where the percentage of respondents born there is $43.4 \%$. Thus those that migrated from outside Lagos is $56.6 \%$ in Ajegunle, $45 \%$ in Ijora Oloye and $49 \%$ in Makoko. Some reasons were given for migration by those born outside the communities are poverty $(52 \%)$, lack of job $(42 \%)$, lack of shelter $(34 \%)$ and family conflict (19\%). Differences were observed in the residency pattern of respondents living in the three communities. While $35 \%$ and $22 \%$ of respondents in Makoko and Ajegunle respectively have been living in the communities between five and ten years, over $45 \%$ of respondents in Ijora Oloye have lived in the community for more than fifteen years.

Most respondents from Ijora Oloye 458 (56.9\%) earn less than N50,000 (USD320) per annum compared with 109 (13.4\%) and 28 (3.4\%) from Ajegunle and Makoko respectively, while very few, $1(0.1 \%), 3(0.4 \%)$ and 2 $(0.2 \%)$ in Ijora Oloye, Ajegunle and Makoko earn close to N400,000 (USD 5,120) per annum. However, majority of respondents from the three slums refused to disclose their income. Most respondents $(92.0 \%)$ from the three communities have residential accommodation, on the other hand, about $1.6 \%$ do not have. About $2.5 \%$ of 
Table 1: Demographic characteristics of the respondents

\begin{tabular}{|c|c|c|c|}
\hline Characteristics & $\begin{array}{c}\text { Ijora Oloye } \\
(n=805)\end{array}$ & $\begin{array}{c}\text { Ajegunle } \\
(n=814)\end{array}$ & $\begin{array}{l}\text { Makoko } \\
(n=815)\end{array}$ \\
\hline \multicolumn{4}{|l|}{$\operatorname{Sex}$} \\
\hline Male & $348(43.2 \%)$ & $387(47.5 \%)$ & $417(51.2 \%)$ \\
\hline Female & $457(56.8 \%)$ & $427(52.5 \%)$ & $398(48.8 \%)$ \\
\hline \multicolumn{4}{|l|}{ Ethnic Group } \\
\hline Yoruba & $746(92.7 \%)$ & $337(41.4 \%)$ & $634(77.8 \%)$ \\
\hline Igbo & $17(2.1 \%)$ & $227(27.9 \%)$ & $125(15.3 \%)$ \\
\hline Hausa & $19(2.4 \%)$ & $8(1 \%)$ & $4(0.5 \%)$ \\
\hline Others & $23(2.8 \%)$ & $242(29.8 \%)$ & $52(6.4 \%)$ \\
\hline \multicolumn{4}{|l|}{ Educational status } \\
\hline No formal schooling & $179(22.2 \%)$ & $86(10.6 \%)$ & $107(13.1 \%)$ \\
\hline Less than Primary school & $33(4.1 \%)$ & $32(3.9 \%)$ & $33(4 \%)$ \\
\hline Primary school completed & $224(27.8 \%)$ & $194(23.8 \%)$ & $201(24.7 \%)$ \\
\hline Secondary school completed & $276(34.3 \%)$ & $417(51.2 \%)$ & $377(46.3 \%)$ \\
\hline Post secondary school completed & $51(6.3 \%)$ & $70(8.6 \%)$ & $70(8.7 \%)$ \\
\hline Postgraduate degree & $6(0.7 \%)$ & $9(1.1 \%)$ & $11(1.3 \%)$ \\
\hline Quranic & $28(3.5 \%)$ & 0 & $8(1 \%)$ \\
\hline No response & $8(1.0 \%)$ & $6(0.7 \%)$ & $8(1 \%)$ \\
\hline \multicolumn{4}{|l|}{ Annual household income } \\
\hline Less than N50,000 (USD 320) & $458(56.9 \%)$ & $109(13.4 \%)$ & $28(3.4 \%)$ \\
\hline N50,000 $\leq \mathrm{N} 100,000$ (USD 640) & $48(6.0 \%)$ & $23(2.8 \%)$ & $19(2.3 \%)$ \\
\hline $\mathrm{N} 100,000 \leq \mathrm{N} 200,000($ USD 1,280$)$ & $6(0.7 \%)$ & $8(1.0 \%)$ & $7(0.9 \%)$ \\
\hline $\mathrm{N} 200,000 \leq \mathrm{N} 300,000($ USD 2,560$)$ & $3(0.4 \%)$ & $2(0.2 \%)$ & $4(0.5 \%)$ \\
\hline $\mathrm{N} 300,000 \leq \mathrm{N} 400,000(\mathrm{USD} 5,120)$ & $1(0.1 \%)$ & $3(0.4 \%)$ & $2(0.2 \%)$ \\
\hline Don't know & $9(1.1 \%)$ & $45(5.5 \%)$ & $16(2 \%)$ \\
\hline No response & $280(34.8 \%)$ & $624(76.7 \%)$ & $739(90.7 \%)$ \\
\hline \multicolumn{4}{|l|}{ Marital status } \\
\hline Single & $170(21.1 \%)$ & $226(27.8 \%)$ & $246(30.2 \%)$ \\
\hline Currently Married & $559(69.4 \%)$ & $518(63.6 \%)$ & $496(60.6 \%)$ \\
\hline Separated & $6(0.7 \%)$ & $13(1.6 \%)$ & $9(1.1 \%)$ \\
\hline Divorced & $2(0.2 \%)$ & $9(1.1 \%)$ & $10(1.2 \%)$ \\
\hline Widowed & $66(8.2 \%)$ & $45(5.5 \%)$ & $49(6 \%)$ \\
\hline Cohabitating & $1(0.1 \%)$ & $3(0.4 \%)$ & $4(0.5 \%)$ \\
\hline No response & $1(0.1 \%)$ & & $3(0.4 \%)$ \\
\hline \multicolumn{4}{|l|}{ Religion } \\
\hline Christianity & $77(9.6 \%)$ & $564(69.3 \%)$ & $526(64.5 \%)$ \\
\hline Islam & $715(88.8 \%)$ & $245(30.1 \%)$ & $276(33.9 \%)$ \\
\hline Traditional & $11(1.4 \%)$ & $3(0.4 \%)$ & $11(1.3 \%)$ \\
\hline Others & $1(0.1 \%)$ & $1(0.1 \%)$ & \\
\hline No response & $1(0.1 \%)$ & $1(0.1 \%)$ & $2(0.2 \%)$ \\
\hline \multicolumn{4}{|l|}{ Occupational status } \\
\hline Civil servant & $34(4.2 \%)$ & $36(4.4 \%)$ & $32(3.9 \%)$ \\
\hline Private sector employee & $46(5.7 \%)$ & $67(8.2 \%)$ & $85(10.4 \%)$ \\
\hline Trading & $367(45.6 \%)$ & $362(44.5 \%)$ & $342(42 \%)$ \\
\hline Farming & $14(1.7 \%)$ & $5(0.6 \%)$ & $2(0.1 \%)$ \\
\hline Artisan & $133(16.5 \%)$ & $161(19.8 \%)$ & $130(16 \%)$ \\
\hline Fisherman & $1(0.1 \%)$ & $1(0.1 \%)$ & $8(1.0 \%)$ \\
\hline Student & $81(10.1 \%)$ & $54(6.6 \%)$ & $74(9.1 \%)$ \\
\hline Housewife & $11(1.4 \%)$ & $25(3.1 \%)$ & $14(1.7 \%)$ \\
\hline Retiree & $30(3.7 \%)$ & $26(3.2 \%)$ & $25(3.1 \%)$ \\
\hline Unemployed & $22(2.7 \%)$ & $30(3.7 \%)$ & $19(2.3 \%)$ \\
\hline Others & $63(7.8 \%)$ & $41(5.0 \%)$ & $83(10.2 \%)$ \\
\hline No response & $3(0.4 \%)$ & $6(0.7 \%)$ & $2(0.2 \%)$ \\
\hline
\end{tabular}

South East Asia Journal of Public Health 2013;3(1):36-41 
Table 2: Language of interview

\begin{tabular}{|l|c|c|c|c|}
\hline Language & $\begin{array}{c}\text { Number (\%) inter- } \\
\text { viewed (Ijora Oloye) } \\
(\mathbf{n = 8 0 5 )}\end{array}$ & $\begin{array}{c}\text { Number (\%) inter- } \\
\text { viewed (Ajegunle) } \\
(\mathbf{n = 8 1 4 )}\end{array}$ & $\begin{array}{c}\text { Number (\%) inter- } \\
\text { viewed (Makoko) } \\
(\mathbf{n = 8 1 5 )}\end{array}$ & $\begin{array}{c}\text { Total } \\
(\mathbf{n = 2 , 4 3 4 )}\end{array}$ \\
\hline English & $77(9.6 \%)$ & $277(34 \%)$ & $192(23.6 \%)$ & 546 \\
\hline Yoruba & $650(80.7 \%)$ & $247(30.3 \%)$ & $562(69 \%)$ & 1,45 \\
\hline Igbo & $1(0.1 \%)$ & $2(0.2 \%)$ & $7(0.9 \%)$ & 10 \\
\hline Hausa & $2(0.2 \%)$ & $12(1.5 \%)$ & $1(0.1 \%)$ & 15 \\
\hline Pidgin & $67(8.3 \%)$ & $234(28.7 \%)$ & $38(4.7 \%)$ & 339 \\
\hline Others & $8(1 \%)$ & $42(5.1 \%)$ & $15(1.8 \%)$ & 65 \\
\hline
\end{tabular}

those who do not have accommodation sleep in mosques, $3.2 \%$ sleep in churches, while $1.2 \%$ stated that they sleep in other places such as market stalls and motor parks. Many respondents (32\%) that have accommodation live in one-room apartment, with an average of 5 people in a room, even as $52 \%$ of those that have accommodation have over 6 individuals per room.

Most respondents $(86.6 \%)$ in the three communities share amenities such as toilet, bathroom and kitchen. However, $43.5 \%$ of them admitted that overcrowding is one of the problems facing them. About $87.5 \%$ of the respondents live on land, while $19.2 \%$ in Makoko live on structures constructed on stilts above the Lagos Lagoon, thus some residents travel through the neighborhood by canoe, boat or over a few wooden bridges and walkways. About $79.6 \%$ of the respondents live in permanent structures made of cement bricks, and are also connected to unsteady electricity, whereas other structures are made of mud, wood or zinc. The source of drinking water to $22.7 \%$ of the respondents was found to be boreholes provided through communal or personal efforts, and the majority depend on water from shallow wells and water vendors for their water supply. Many respondents $(48.8 \%)$ depend on pit latrines located at the back of their houses, just as $36.3 \%$ make use of flush system, while the rest use the lagoon or non -designated latrine areas as a toilet. The popularity of pit latrines is attributed, by some respondents, to the irregularity of the water supply, which makes it difficult to maintain flush toilets.

Most respondents (68\%) do not feel that they live in a hygienic environment, and $79 \%$ feel that their unhealthy environment has led to diseases or ill health in their families, while only $11 \%$ are happy in their current locations. Difficulties faced by respondents are unclean latrine facilities $(54.4 \%)$, perennial flood $(30.1 \%)$, unemployment $(22.6 \%)$, mosquitoes $(89.3 \%)$, lack of electricity supply (63.2\%) and extreme heat (55.7\%). Common diseases mentioned by the respondents are malaria
(86.3\%), diarrhea (59\%) and cough (42.2\%) (Table 3).

\section{Discussion}

This study was conducted in three slum settlements of Lagos metropolis, south western Nigeria so as to highlight the living conditions as well as the health issues facing the slum residents, and thus inform decisions on the relevant interventions. The participants are mainly migrants from other parts of the country who live in unhygienic conditions and work in the informal service sector of the city. The main reasons for migration are poverty and unemployment, while the people are faced with poor living conditions and poor access to safe and adequate drinking water, toilets and proper garbage and sewage disposal mechanisms, which pre-dispose them to illnesses.

According to the United Nations Human Settlements Programme (UN-Habitat), one city dweller in three lives in slum conditions; ${ }^{10}$ however, Africa has a larger urban population than North America or Western Europe, and more than 6 in 10 Africans who live in urban areas reside in slums. ${ }^{11}$ A report of World Health Organization highlighted that almost 137 million people in urban populations have no access to safe drinking water, and more than 600 million urban dwellers do not have adequate sanitation. ${ }^{12}$ Majority of slum dwellers migrated to cities for economic reasons, and in turn suffer unacceptable levels of hygiene and health, while they are deprived of essential basic social facilities. ${ }^{13}$ Other studies from countries like Bangladesh and Kenya show that children living in informal urban settlements are particularly vulnerable to infectious diseases such as diarrhoea, cold and cough and high rate of under-five mortality. ${ }^{11,14-19}$ For example, in Kenya where around two third of the population of Nairobi metropolitan lives in crowded informal settlements, there is an alarming under-five mortality rate of 151 per thousand live births, ${ }^{20}$ while infections such as pneumonia and diarrhoeal are among the leading causes of death. ${ }^{21}$

Table 3: Common diseases in the three communities

\begin{tabular}{|l|c|c|c|c|}
\hline Diseases & Ijora Oloye & Ajegunle & Makoko & Total \\
\hline Malaria & $619(77 \%)$ & $724(89 \%)$ & $757(93 \%)$ & $2100(86.3 \%)$ \\
\hline Diarrhea & $450(56 \%)$ & $504(62 \%)$ & $480(59 \%)$ & $1434(59 \%)$ \\
\hline Cough & $386(48 \%)$ & $276(34 \%)$ & $366(45 \%)$ & $1028(42.2 \%)$ \\
\hline
\end{tabular}


This disadvantaged and vulnerable groups of people are generally aware of illnesses and treatment, however their healthcare seeking behavior is largely limited by the lack of financial resources. ${ }^{22}$ It is important to note that slum dwellers are human capital who contributes greatly to the economies and work forces of their respective countries. ${ }^{23}$ However, the problems facing them, though important, are numerous, but piecemeal solutions will not be adequate and cost effective enough to improve their health. Since Nigeria is presently faced with a dwindling economy and limited funds, a detailed and cost-effectiveness analysis of comprehensive interventions would therefore be needed. This will help create a strategy for sustainable improvements in the quality of life of this vulnerable population and alleviate their suffering.

\section{Conclusion}

Economic growth in Nigeria is not as fast as the rate of growth of its urban populations, and this has given rise to an increasing growth of the populations that have outpaced the country's health and social services. The result of which is increasingly high rates of unemployment, poverty and poor health outcomes especially among the urban poor who live below the poverty line with limited access to social and health care services. In such circumstances, slum living is an unavoidable reality. Therefore to address the health concerns of urban slum dwellers in particular, government should focus on multiple interventions so as to take care of the connectedness of their problems, and not just curative or preventive approach which would probably be less effective. This means that intervention packages that address health service provision, environmental sanitation, personal hygiene, health care seeking behavior, and livelihood opportunities will most likely have greater impact. We therefore recommend that all levels of government sectors in the country should develop strategies for infrastructure creation and sustainable development so as to build the numerous slums in the country into sustainable communities.

\section{Acknowledgement}

The authors appreciate the authorities of Ajeromi Ifelodun, Apapa and Mainland Local Government Areas for granting the team access to the study communities. We are also grateful to the community leaders and residents of Ajegunle, Ijora Oloye and Makoko communities for their cooperation while the study lasted.

\section{Funding}

This study was funded by a seed grant awarded to AOP by the International Association of National Public Health Institutes (IANPHI).

\section{Competing interest}

We declare that we have no competing interest with the preparation and publication of this manuscript.

\section{References}

1. UN-HABITAT (United Nations Human Settlements Programme). The challenge of slums: Global report on human settlements. London: Earthscan Publications, 2003.

2. World Urban Forum on "cities Without Slums," Nairobi, 29 April - 3 May, 2002. HSP/WUF/1/ DLG.1/Paper.

3. Chome J. Behavioural and spatial impacts of title registration in informal settlements: the case study of Blantyre City, Mexico. Enschede, Netherlands: International Institute for GeoInformation Science and Earth Observation, 2002.

4. Agbola T, Olatubara CO. Private sector driven housing delivery (in Nigeria): Issues, constraints, challenges and prospects. Second Annual National Workshop on Private sector Driven Housing Delivery in Nigeria, University of Lagos, Lagos, 30 June- 3 July, 2003.

5. Agbola T, Agunbiade EM. Urbanization, slum development and security of tenure: the challenges of meeting Millennium Development Goal (MDG 7 in metropolitan Lagos, Nigeria. Paper presented to the PRIPODE workshop on Urban Population, Development and Environment Dynamics in Developing Countries. Nairobi, 11-13 June 2007.

6. Okusipe OM. Lagos Lagoon Coastal Profile: Information Database for Planning Theory. Lagos: Department of Urban and Regional Planning, University of Lagos, 2003.

7. Abumere SI. The State of Lagos Mega City and other Nigerian Cities. Lagos: Ministry of Economic Planning and Budget, 2004.

8. National Population Commission, Nigeria. Population distribution by sex and class-size of household. Volume IX. Abuja: National Population Commission, 2007.

9. Dean AG, Dean JA, Coulombier D, Brendel KA, Smith DC, Burton AH, Dicker RC, Sullivan K, Fagan RF, Arner TG. Epi Info Version 6: A Word Processing, Database, and Statistics Program for Epidemiology on Microcomputers. Atlanta, GA: Centers for Disease Control, 1994.

10. UNICEF. The state of the world's children 2012. New York: United Nations Children's Fund, 2012.

11. World Health Organization and United Nations Human Settlements Programme. Hidden Cities: Unmasking and overcoming health inequities in urban settings. Geneva: World Health Organization, 2010. 
12. WHO, UNICEF. Progress on Drinking Water and Sanitation: Special Focus on Sanitation. Geneva: World Health Organization, 2008.

13. Satterthwaite D. The transition to a predominantly urban world and its underpinnings. London: International Institute for Environment and Development, 2007.

14. Sverdlik A. Ill-Health and Poverty: A literature review on health in informal settlements. Environ Urban, 2011;23:123-55.

15. Islam N, Huda N, Narayan FB, Rana PB. Addressing the urban poverty agenda in Bangladesh. Dhaka: The University Press Limited;
1997.

16. Barkat A, Rahman MU, Bose ML. Family planning choice behaviour in urban slums of Bangladesh: an econometric approach. Asia Pac Popul J 1997;12:17-32.

17. Rahman MM, Shahidullah M. Risk factors for acute respiratory infections among the slum infants of Dhaka city. Bangladesh Med Res Counc Bull 2001;27:55-62.

18. Barrett, Julia R. A Marked Disadvantage: Rapid urbanization and mortality of young children in Nigeria. Environ Health Perspect 2010; 118:118259. 